\title{
The Quality of Mandatory Disclosure by Listed Companies in Bangladesh
}

\author{
Mohammad Abu Sufian \\ Department of Business Administration, Pabna University of Science and Technology, Pabna, Bangladesh
}

Email address:

md.abu_sufian@yahoo.com

\section{To cite this article:}

Mohammad Abu Sufian. The Quality of Mandatory Disclosure by Listed Companies in Bangladesh. Journal of Finance and Accounting. Vol. 4, No. 4, 2016, pp. 194-201. doi: 10.11648/j.jfa.20160404.15

Received: May 23, 2016; Accepted: June 5, 2016; Published: June 23, 2016

\begin{abstract}
The main thrust of this paper is to assess the level of mandatory disclosures attributable to the quality of mandatory disclosure practices by the listed companies in Bangladesh. It is also designed to examine the trend of disclosure over the year and to investigate the variation of disclosure across the samples and industries for measuring the quality of disclosure practices. Thirty annual reports for the year 2006-2010 of non-financial companies with listed Dhaka Stock Exchange in Bangladesh have been considered as sample to find the empirical result of this study. The outcome of the analysis reveals that the mean score of mandatory disclosure is 59.28 percent with a range of $45.34 \%$ to $71.85 \%$ and 87 percent of sample companies have shown a significant difference in the disclosure scores in their annual reports. The T-test result shows that there is a significant variation of disclosure among the sample firms and a little variation is observed over the years. But the result of F-test reports no variation of disclosure across the industrial sectors. The overall findings of this study is that the quality of mandatory disclosure practiced by listed companies in Bangladesh is being improved over the years at a little variation.
\end{abstract}

Keywords: Mandatory Disclosure, Non-financial Companies, Trend, DSE, Reporting Environment

\section{Introduction}

Now-a-days accountability and transparency are much inequitable for the competitive global business sectors due to their increasing control of economic activities. Meaningful communication through disclosure stimulates transparency and accountability [10]. Generally disclosure refers to effective communication of formal information of accounting report inconformity with relevant Acts, Rules and Standards. It is the communication of both financial and non-financial information about economic entity. It includes reporting information about an enterprise's revenues, costs, earnings, resources, obligations, employees, production and investment plans etc. In Bangladesh, disclosure of information is made generally in two ways. The first type of disclosure is made through prospectus when new securities are offered in the primary market. The second type of disclosure of information is made in annual reports through the various financial statements and accompanying notes.

Corporate mandatory disclosure is the minimum regulatory requirement that implies the presentation of financial and non financial information in corporate annual reports that is required by regulatory authorities including the Standard Setting Bodies, the Stock Exchange Authorities and Securities and Exchange Commission. The minimum level of corporate mandatory disclosure is defined by accounting standards, the legal framework of a country (Companies Act 1994, Banking Company Act 1991 and Income Tax Ordinance 1984), industrial norms or standards and stock market requirements. This disclosure should be adequate in corporate annual reports. Adequate disclosure is a function of the quantity and quality of information disclosed timely in annual reports with maintaining established Standards and Act. According to [13] and [39] disclosure of information in corporate annual reports is considered 'adequate' if it is relevant to the needs of users, capable of meeting those needs, and timely released. [31] defines adequate disclosure as the extent (no. of items) to which mandated applicable information is presented in annual reports of companies and the degree of intensity by which a company discloses those items in its annual report. The Companies Act, 1994 
prescribes uniform disclosure requirements for all companies irrespective of their size, nature and ownership.

Thus, mandatory disclosure is a function of Laws, Acts and Regulations that refers to the minimum regulatory requirement set by the regulatory authorities including the Standard Setting Bodies and the Stock Exchange Authorities. It should be adequate, full and fair in corporate annual reports for financial decision making.

In the recent years, the regulatory authorities of Bangladesh have taken some measures to improve and promote the quality of disclosure practices by listed companies in Bangladesh. Such measures have included the adoption of International Accounting Standards (IASs) and International Standards on Auditing (ISA), the enactment of the improved Companies Act in 1994, the amendment of Security and Exchange Rules in 1987, the issuance of Corporate Governance Guidelines in 2006 and the Listing Regulation in 1996. Now the issue of disclosure has become an emerging field of research in Bangladesh and a number of researchers are contributing in this field. The recent research works of [2], [5], [7, 8], [11], [15], [17, 18], [26], [21] .. [24], [27], [34, 35] and [37] on disclosures of various issues are available in Bangladesh.

\section{Justification and Objectives of the Study}

In Bangladesh, regulatory environment has been developed by the collective contributions of professional, private and public institutions. The national components making collaboration with some international components are actively engaged in developing legal framework are two categories i.e., institutional and professional. The institutional components that have a great contribution in this field are Registrar of Joint Stock Companies, Stock Exchanges, Bangladesh Securities and Exchange Commission, Bangladesh Enterprise Institute (BEI), Public Accounts Committee of the Parliament, the Office of the Comptroller and Auditor General of Bangladesh and the concern Ministry of the Government of Bangladesh. On other hand, the Professional Accounting Bodies, the Institute of Chartered Accountants of Bangladesh (ICAB) and the Institute of Cost and Management Accountants of Bangladesh (ICMAB), are doing a proactive role to develop and issue a sound professional ethics, code of conduct and other pronouncements for their professional accountants. These two components are promulgating some statues and adopting some standards to strengthen the financial reporting in annual reports and auditing practices respectively.

The industrial development in Bangladesh is gradually increasing over the years. In line with industrial development the regulatory environment in Bangladesh is changing over the period. But the outcomes of the policies set by regulatory bodies are not expected. It is evident from the prior studies of [1], [3], [7], [9], [10], [12], [14] and [32]. These studies reported that the extent of mandatory disclosure of manufacturing sector is poor while the studies of [5], [18], [27] and [33], revealed that the listed companies do not comply all mandatory disclosure requirements in their annual reports. Moreover, a very little awareness of investors, loopholes of existing laws and acts, the strong opponents and the absent of pressure groups are the reasons of low compliance of mandatory disclosure. But the importance of disclosure issues is evident in the developed world because of a series of accounting scandals made by the auditing firm named Arthur Andersen, by the telecommunications company named WorldCom and by the energy giant, Enron. As the reporting environment of the developing countries especially in Bangladesh are more fragile as compared to those of developed world, this issue claims more emphasis in this country. In addition to these, this issue has become an eye catching issue after the two times debacle of stock market occurred in 1996 and in 2010. Disclosure practices enhance the green image of companies to the shareholders and others. The proper disclosure of relevant information in the financial statements of a company is of great importance. Adequate disclosure is the most important way by which we can meet the information needed of diverse interest groups for rational decision making. Meaningful communication through disclosure ensures transparency, accountability, fairness and responsibility. Since the ultimate objective of disclosure is to communicate timely, reliable and material information which is useful to the users of annual reports, the present study is justified on the grounds that the subject matter is important and there is a lack of researches on this area. Realizing these facts, a modest attempt is made to see the present level of mandatory disclosures leading to the quality of disclosure practices by the listed companies in Bangladesh. Also, it is going to examine the trend of disclosure over the year and to see the variation among the samples and industries.

\section{Review of Literatures and Development of Hypotheses}

This section provides a critical review of prior research works already done in the proposed field in order to identify the hiatus or knowledge gap in the field of proposed research, to enhance our understanding the disclosure practices and to develop the hypotheses.

The study of [1] reported that the degree of compliance was low, since none of the companies in Bangladesh disclosed all mandatory items. It also showed a variation of disclosure among samples companies i.e. 58.7 percent companies disclosed between 60 percent to 80 percent items of disclosure. Another study by [7] revealed that disclosure compliance was poor among listed companies and the level of disclosure was 43.53 percent with a range of 17.3 percent to 72.5 percent. He concluded that many corporate annual reports did not meet the disclosure requirements of the regulatory bodies in Bangladesh. The research work of [5] revealed that the listed companies in Bangladesh did not 
meet the legal and mandatory disclosure levels framed by different regulatory bodies. Overall disclosure level was below average $(37.60 \%)$ reported in this study. [2] did not find full compliance among the sample firms. The similar result was found by the study of [17]. The research of [33] showed that companies did not comply with all mandatory disclosure requirements in annual reports. This result was consistent with the result of [34].

The disclosure compliance of companies examined by the global studies is mixed. The research work of [41] reported that the current level of compliance with the mandatory disclosure requirements was naturally high among Chinese listed companies. The counter result was found by the research work of [38] that examined 85 percent companies scored less than 50 on the Corporate Transparency Index (CTI).[36] found extremely poor level of disclosure made by financial institutions in their annual reports in Uganda. [4] revealed that the companies disclosed, on an average, 81 percent mandatory and 27 percent voluntary information items in the annual reports of non-financial companies listed both on Mumbai Stock Exchange and Delhi Stock Exchange while [20] found the extent of mandatory and voluntary disclosure by listed banking companies in India was 88 and 25 percent respectively.

[29] reported that all industrial sectors except electricity sector complied with the mandatory disclosure requirements evidence from the listed Saudi nonfinancial companies. The research results of [25] indicated that Malaysian Companies disclosed all the mandatory financial statements and relevant notes to the accounts in accordance with KLSE Listing Requirements. The study of [31] revealed that the Zimbabwe firms disclosed, on an average, 74.43 percent mandatory items in their annual reports. An analysis of the determinants of disclosure in the Portuguese stock exchange, [28] have studied the determinants of mandatory disclosure practices by Portuguese listed companies resulted that the mean disclosure of companies is $44 \%$ with a range of $16 \%$ to $64 \%$. [19] suggested that Egyptian companies did not tend to fully comply with mandatory disclosure and that voluntary disclosure was rather limited i.e. companies published $90 \%$ of the list of mandatory information items (49 items) and $48 \%$ of the list of voluntary information items (26 items). The empirical result of the study of [16] reported that non-financial Greek firms, on average, disclosed $86 \%$ of the mandatory information in their annual reports. The research work of [40] measured the mean level of disclosure of firms listed on the stock exchange of Hong Kong was $73 \%$ with a range of scores for the disclosure index varies from $55 \%$ to $87 \%$.

In line with the above researchers the first endeavor of this study is to measure the extent of mandatory disclosure practices by listed companies in Bangladesh.

The second initiative of the study is motivated from the point that the regulatory requirements of our country have been changed over the period 2006 to 2010. Now the question raises the quality or the improvement of disclosure during the study period and an alternative hypothesis may be done as follows:
$\mathrm{H}_{\mathrm{A}-1}$ : There is a significant variation of the extent of mandatory disclosure over the years.

From the prior research works it is proved that companies do not tend to fully comply with all mandatory disclosure and there is a variation in the disclosure index. In this situation another alternative hypothesis can be drawn as:

$\mathrm{H}_{\mathrm{A}-2}$ : There is also a significant variation of the extent of mandatory disclosure among the sample firms.

Similarly, it can be hypothesized as

$\mathrm{H}_{\mathrm{A}-3}$ : There is also a significant variation of the extent of mandatory disclosure across the industrial sectors.

\section{Methodology of the Study}

The study is based on secondary data taken from the annual reports of 30 non financial companies listed on the Dhaka Stock Exchange for 5-year study period starting from 2006 to 2010. The reporting period of the companies falls at the end of December have taken sample purposively. The name of sample companies and their symbolic code are displayed in table 1 . Then a disclosure index comprising of 204 mandatory items has been made by explaining the legal statues and standards applicable in Bangladesh. The said items are scored based on the relative unweighted approach under a dichotomous procedure where a relevant item scores one if it is disclosed, N/A for non-applicable items and zero for otherwise for each company consistent with [36]. Proportionate scores have been assigned for sub items and then total relative disclosure scores have been obtained adding up all the items disclosed by the company. Then total items applicable to disclose have been got by deducting the total number of non-applicable items. The following formula is used for construction of RMDI:

$$
\begin{gathered}
R M D I=\frac{\text { Total Items Disclosed in Annual Report }}{\text { Total Items Applicable to Disclose in Annual Report }} \\
\text { Symbolically, } R M D I=\frac{\sum_{i=1} d m_{i}}{\sum_{i=1} d n_{i}}
\end{gathered}
$$

Where $d=1$ if a relevant item is disclosed, 0 if that item is not disclosed

$\mathrm{m}=$ number of items disclosed

$\mathrm{n}=$ maximum number of disclose able items

To assess the degree of mandatory disclosures made by listed companies of Bangladesh and to see the improvement of disclosure, the descriptive analysis, F-test and T-test have been used. The Statistical Package for the Social Sciences (SPSS) has been run to analyze the collected data.

\section{Results and Discussion}

\subsection{Total Disclosure Scores of the Sample Companies}

Table 1 shows the disclosure scores of sample manufacturing companies for the year 2006 to 2010. The mean scores of the periods indicate that highest disclosure level 
(59.66 percent) is found in the year 2010 and the lowest disclosure level (59.05 percent) is observed in 2007. The mean score is 59.25 percent observed in 2006. It is seen from the table that the mean disclosure scores of the sample companies are increasing. However, the percentage of its increase over the study period is quite low. Again, yearly average rate of increase is 0.23 percent, 0.18 percent, and 0.63 percent in 2008, 2009 and 2010 respectively. The 5-year average mean score is $59.28 \%$. In the year 2006, 2007 and 2008 the mean score $59.25,59.05$ and 59.18 respectively are below the average mean while the mean score 59.66 of the year 2010 is above the average mean score. The highest of maximum disclosure score i.e., 71.58 is seen in the year 2010 and the lowest of maximum disclosure score i.e., 67.46 is seen in 2006 while the highest of minimum disclosure score i.e., 48.35 is seen in the year 2010 and the lowest of minimum disclosure score i.e., 45.34 is seen in 2006. This indicates the variation of the disclosure score over the study periods.

Tab. 1. Name, code of Sample Companies and their disclosure scores (in percentage).

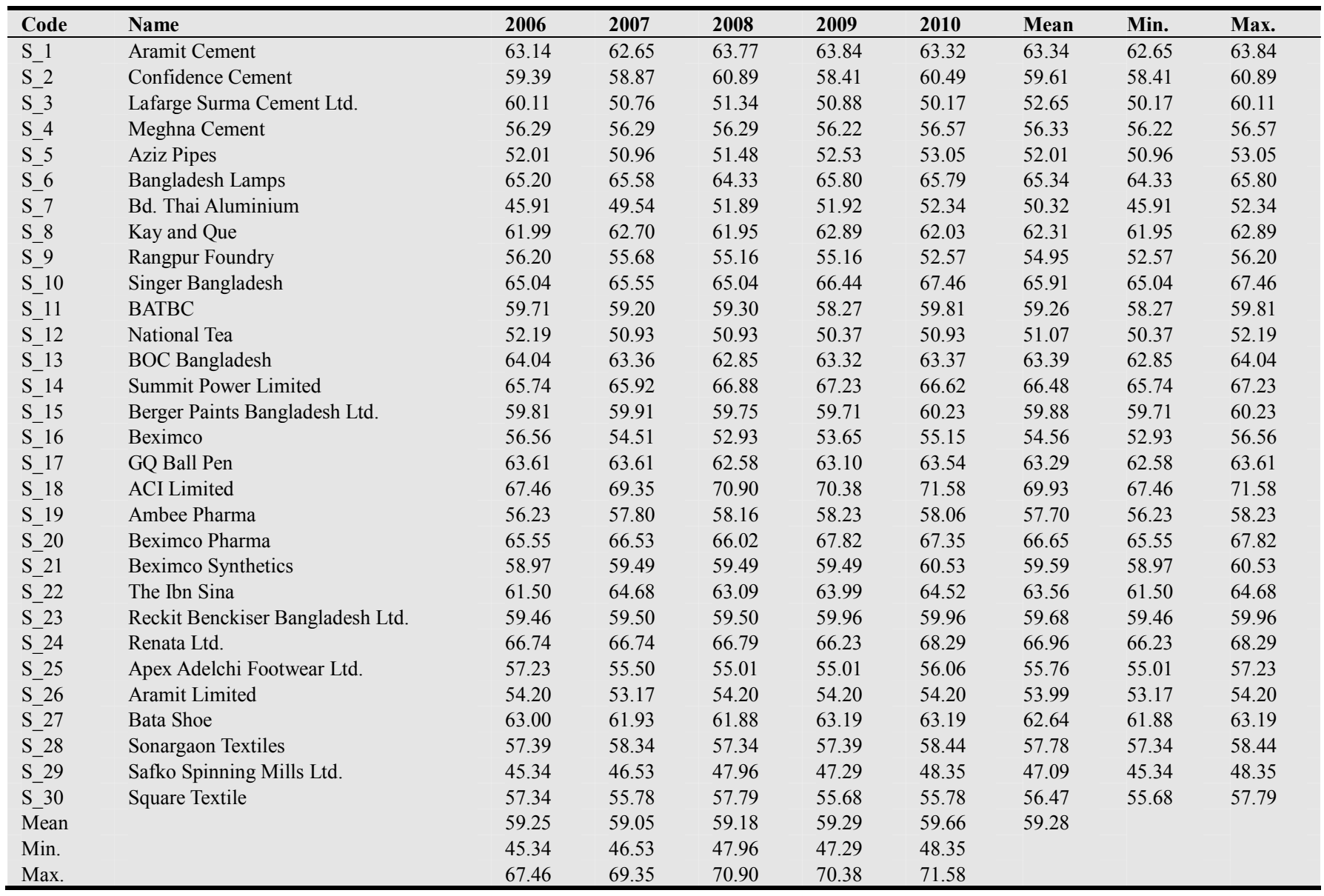

The mean scores of total disclosure of sample companies imply the overall disclosure levels disclose the highest mean disclosure score is being made by the sample company 18 i.e., ACI Limited and the least of that is being made by the sample company 29 i.e., Safko Spinning Mills Limited. The overall disclosure may be regarded as relatively poor in all sample companies because the highest scorer company represents only $69.93 \%$ of maximum attainable of 204 mandatory items of our disclosure index. Among 30 companies only 5 companies show an increasing trend of disclosure items while others show the mixed pattern of disclosure practice. The mean of five year average of all sample companies is 59.28. Fifty three (16 companies) percent of the selected sample companies show more than this average disclosure score while 47 (14 companies) percent of the selected sample companies have shown below average disclosure scores. The highest of maximum and the highest of minimum disclosure score both are observed in case of the sample number 18 while the lowest of maximum and the lowest of minimum disclosure score both are identified in case of sample company 29. As the sample-wise mean disclosure scores is in between 47.09 to 67.46 , the extent of overall disclosure is regarded as moderately poor.

\subsection{Descriptive Statistics}

Table 2 indicates that the mean level of disclosure reported in the annual reports of listed companies is 59.28 percent with a range of 45.34 percent to 71.85 percent. First and third quartile implies that sample companies disclose on average 55.16 percent and 63.61 percent items of disclosure. It is evident from the table that Bangladeshi companies do not comply with $100 \%$ mandatory disclosure practice in their annual reports. 
Tab. 2. Descriptive statistics of panel data.

\begin{tabular}{|c|c|c|c|c|c|c|}
\hline Variable & Minimum & Maximum & Mean & Std. Deviation & 25thPercentile & 75thPercentile \\
\hline Relative Mandatory Disclosure Score & 45.34 & 71.58 & 59.2837 & 5.73489 & 55.16 & 63.61 \\
\hline
\end{tabular}

\subsection{Graphical Trend of Disclosure}

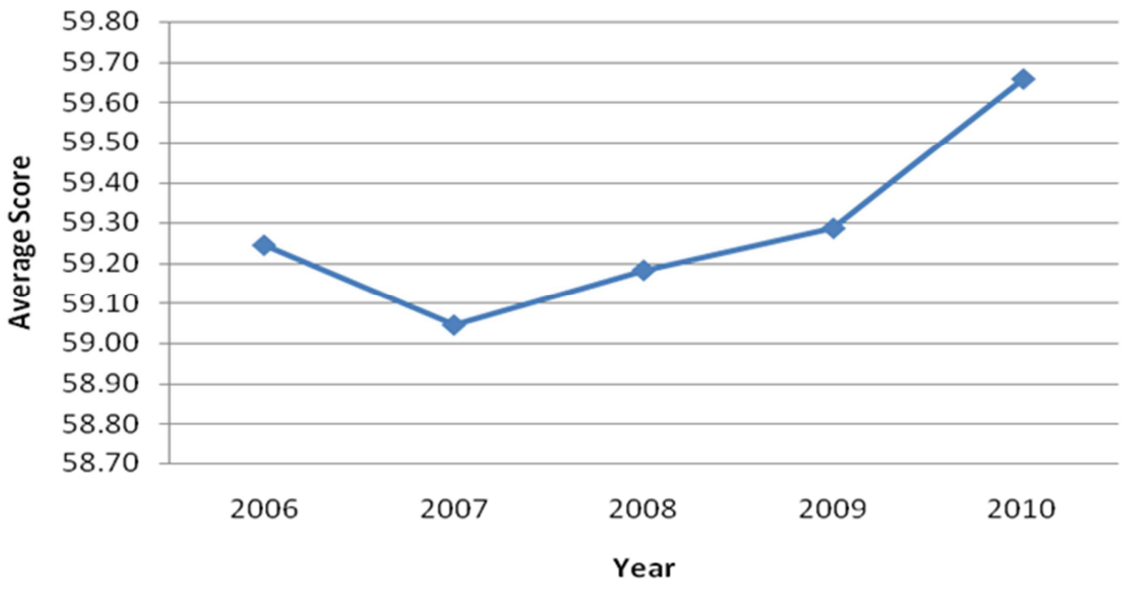

Fig. 1. Trend of disclosure of the sample companies.

Figure 1 shows the trend of disclosure of the selected manufacturing companies during the period under study. Peak point i.e. highest score of the trend line is seen in 2010 and the trough point i.e. lowest score is seen in 2007. From the trough point the trend is increasing sharply over the period of four year i.e., 2007-2010. Thus, the figure tells us that there is a little variation of disclosure score of sample companies over the years.

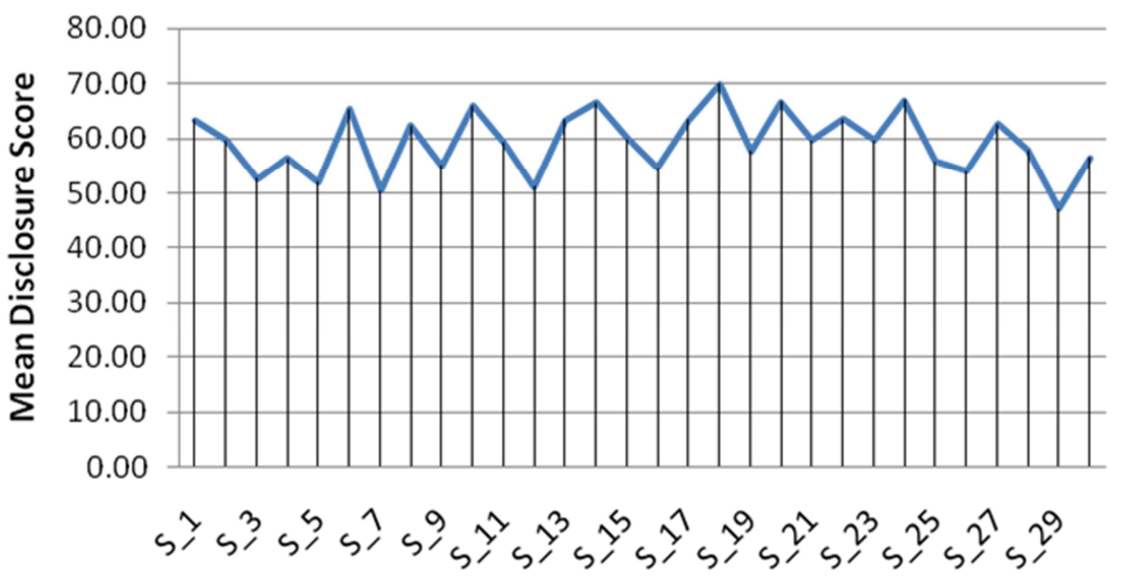

\section{Sample Company}

Fig. 2. Company-wise average disclosure scores.

Figure 2 represents the sample-wise average disclosure scores indicates that the highest score is observed in the case of sample 18 and lowest for sample 29 under un-weighted disclosure index. Disclosure scores of different sample companies are very close to each other as the mean variation is $0.95 \%$. The figure reports that only 12 companies are practicing standard level of disclosure among sample companies taking overall mean disclosure score 59.28 as standard level. It can be also seen from the line graph is that a half of the total companies secures below and above 60 percent disclosure score and only one company is practicing below 50 percent disclosure. Thus, it can be inferred that there is a variation of disclosure among the sample companies.

\subsection{Distribution of Disclosure Scores}

Figure 3 represents the distribution of disclosure made by different sample companies. It expresses the percentage of sample companies that fall in a specific score range. It is seen that $33 \%$ of sample companies show disclosure performance in between $55 \%-60 \%$ and $23 \%$ of the sample are in the range of $50 \%-55 \%$. Highest and second highest score range have been attained by $20 \%$ and $20 \%$ sample companies respectively. But no firm secures below $45 \%$ score. 


\section{$\%$ of Sample Firm}

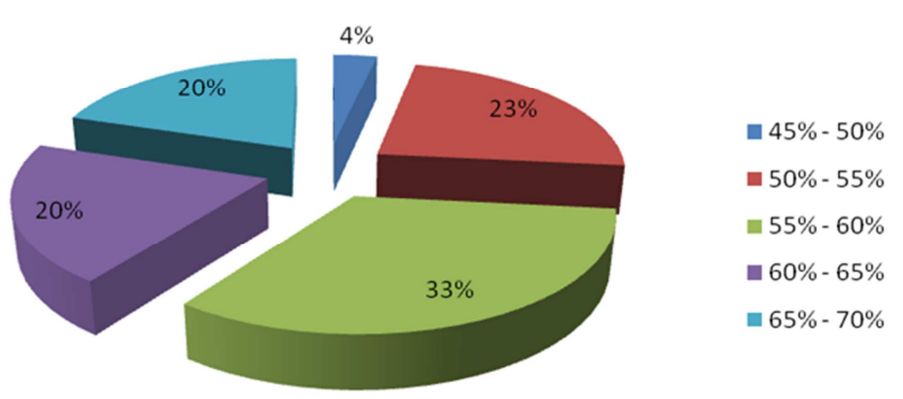

Fig. 3. Disclosure score shared by the sample companies.

\subsection{Variation of Disclosure over the Years}

Tab. 3. Result of paired sample t-test of total disclosure Score (Year-wise).

\begin{tabular}{|c|c|c|c|c|c|c|c|c|c|}
\hline \multicolumn{7}{|c|}{ Paired Differences } & \multirow{3}{*}{$\mathbf{t}$} & \multirow{3}{*}{ df } & \multirow{3}{*}{ Sig.(2-tailed) } \\
\hline \multicolumn{7}{|c|}{ 95\% Confidence Interval of the Difference } & & & \\
\hline & & Mean & Std. Deviation & Std. Error Mean & Lower & Upper & & & \\
\hline Pair 1 & Y 2006 - Y 2007 & .19967 & 2.16622 & .39550 & -.60921 & 1.00855 & .505 & 29 & .617 \\
\hline Pair 2 & Y_2007 - Y_2008 & -.13767 & 1.05106 & .19190 & -.53014 & .25480 & -.717 & 29 & .479 \\
\hline Pair 3 & Y_2008 - Y_2009 & -.10367 & .94933 & .17332 & -.45815 & .25082 & -.598 & 29 & .554 \\
\hline Pair 4 & Y_2009 - Y_2010 & -.37167 & .95453 & .17427 & -.72809 & -.01524 & -2.133 & 29 & .042 \\
\hline Pair 5 & Y_2006 - Y_2010 & -.41333 & 2.71376 & .49546 & -1.42667 & .60000 & -.834 & 29 & .411 \\
\hline Pair 6 & Y_2006 - Y_2008 & .06200 & 2.40598 & .43927 & -.83641 & .96041 & .141 & 29 & .889 \\
\hline Pair 7 & Y_2006 - Y_2009 & -.04167 & 2.49305 & .45517 & -.97259 & .88925 & -.092 & 29 & .928 \\
\hline Pair 8 & Y_2007 - Y_2009 & -.24133 & .85799 & .15665 & -.56171 & .07905 & -1.541 & 29 & .134 \\
\hline Pair 9 & Y_2007 - Y_2010 & -.61300 & 1.10400 & .20156 & -1.02524 & -.20076 & -3.041 & 29 & .005 \\
\hline Pair 10 & Y_2008 - Y_2010 & -.47533 & 1.10063 & .20095 & -.88631 & -.06435 & -2.365 & 29 & .025 \\
\hline
\end{tabular}

In order to test whether there is any significant difference in the total mean disclosure scores (year-wise) of the nonfinancial companies, paired sample T-test have been used. The $t$ values of the Table 3 states that pair 4, 9 and 10 are significant at $5 \%$ level. Hence, the null hypothesis is rejected for the three cases. Therefore it may be concluded that there are significant variation between the extent of disclosure practices of 2007-2010, 2008-2010, and 2009-2010. Another point is noted that only in 30 percent of the cases, a statistical significant difference in the disclosure scores in their annual reports has been revealed over the period. Thus, it implies that there is no significant deviation in disclosure scores during the period under study.

\subsection{Variation of Disclosure Among the Sample Firms}

Hypothesis $\mathrm{H}_{\mathrm{A}-2}$ has been tested by applying paired sample T-test of company-wise total disclosure scores. The test yields the results that $t$ values of 380 pairs out of 435 pairs are significant at $5 \%$ level. It indicates that 87 percent of sample companies have shown a significant difference in the disclosure scores in their annual reports and an insignificant difference has been revealed by only 13 percent sample companies. Hence, the alternative hypothesis is accepted at 87 percent cases. Therefore, the differences in the extent of disclosure practices among the sample companies are significant at 5\% level.

\subsection{Disclosure Trend Across the Industrial Sectors}

One-way ANOVA has been used to test hypothesis HA-3 i.e., the trend of disclosure across the industrial sectors. Table 4 shows the result of F-test. The probabilities of F-test for all years are greater than 0.05 values. Hence the test is insignificant at 0.05 level that rejects the alternative hypothesis, $\mathrm{H}_{\mathrm{A}-3}$. It indicates that there is no significant variation of disclosure over the industrial sectors.

Tab. 4. The Results of F-test.

\begin{tabular}{llllll}
\hline Year & $\mathbf{2 0 0 6}$ & $\mathbf{2 0 0 7}$ & $\mathbf{2 0 0 8}$ & $\mathbf{2 0 0 9}$ & $\mathbf{2 0 1 0}$ \\
\hline 1-way ANOVA: F & 1.352 & 1.632 & 1.646 & 1.925 & 1.685 \\
Ratio P-value & .274 & .179 & .175 & .114 & .165 \\
\hline
\end{tabular}

**All insignificant at $5 \%$ critical level

\section{Conclusion}

The main aim of this paper is to assess the extent of mandatory disclosure practices as an evidence of the quality of disclosure practices by the listed companies in Bangladesh. The second measure of the improvement of disclosure practices is to see the variation among the sample firms, industries and over the years. In these regards, a survey of 30 companies listed with DSE for the year 2006-2010 has been 
conducted. To measure the quality of mandatory disclosures made by listed companies of Bangladesh, various statistical tools such as trend analysis, descriptive analysis, F-test and Ttest have been used. An unweighted mandatory disclosure index of 204 items has been constructed by critically examining the statutory requirements set by regulatory bodies. The descriptive results of panel data indicate that the average mean score is 59.28 percent with a minimum and maximum level of $45.34 \%$ to $71.85 \%$ respectively. This result is consistent to the result of [1] where the mean score is 58.7 percent and that of [30] where the mean score is 63.51 percent. This confirms that Bangladeshi companies do not disclose $100 \%$ mandatory disclosure items in their annual reports. The same opinion has been passed for Zimbabwe, Pakistan, and Indian firms as the average mandatory disclosure is $74.43 \%$ [31], 81\% [6] and $81 \%$ [4] respectively. The study of [31] and [6] showed the improved quality of disclosure where the mean score is 74.43 percent and 78 percent respectively because these study have only conducted on disclosure of accounting standards. Whereas the present study shows better quality of disclosure compared to the findings $(43.53 \%)$ of [7] and the findings (37.60) of [5]. The T-test result shows that there is a significant variation of disclosure among the sample firms and a little variation is observed over the years. But the result of Ftest reports no variation of disclosure across the industrial sectors. The overall findings of this study is that a little improvement of the quality of mandatory disclosure is practiced by listed companies in Bangladesh. To improve the quality of disclosure a good reporting environment with a separate Financial Reporting Act should be enacted and a monitoring body including private and public institutions should be established to ensure accountability and responsibility. ICAB should be more conscious about the activities of auditors, financial accountants and managers of a firm. Having some practical implications, this study does not show the association between the extent of disclosure and the company characteristics. By taking more samples a longitudinal study with primary data may be conducted to have the depth understanding of the mandatory practices of corporate disclosure in Bangladesh for the avenue of further research.

\section{References}

[1] Ahmed, K. and Nicholls, D. (1994) 'The Impact of Nonfinancial Company Characteristics on Mandatory Disclosure Compliance in Developing Countries: The case of Bangladesh', The International Journal of Accounting, Vol. 29, pp. 62-77.

[2] Ahmed, M. U., Bala, S. K. and Chowdhury, A. (2004) 'Financial Reporting in Compliance with International Accounting Standards: A study in Bangladesh with reference to IAS 1', Dhaka University Journal of Business Studies, Vol. 25, No. 2, pp. 17-52.

[3] Ahmed, K. (1996) 'Disclosure policy choice and corporate characteristics: A study of Bangladesh', Asia Pacific Journal of Accounting, pp. 184-203.
[4] Ahmed, H. and Miya, M. T. I. (2007) 'Firm's Trading Status in the Stock Market and the Extent of Disclosure in India', The Cost and Management, Vol. 35, No. 6, pp. 46-51.

[5] Alam, J. (2007) 'Financial Disclosure in Developing Countries with Special Reference to Bangladesh', Ph.D. Dissertation, University of Ghent, Belgium.

[6] Ali, M. J., Ahmed, K and Henry, D. (2004) 'Disclosure compliance with national accounting standards by listed companies in South Asia', Accounting and Business Research, Vol. 34, No. 3, pp. 183-199.

[7] Akhtaruddin, M. (2005 $)$ 'Corporate Mandatory Disclosure Practices in Bangladesh', The International Journal of Accounting, Vol. 40, pp. 399-422.

[8] Akhtaruddin, M. (2005 $)$ 'Mandatory Disclosure and its Association with Company Age: A study of Listed Companies in Bangladesh', Journal of the Institute of Bangladesh Studies, Vol. 28, pp. 33-50.

[9] Akhtaruddin, M. and Haron, H. (2012) 'Mandatory compliance by publicly listed companies in Malaysia', Int. J. Accounting, Auditing and performance Evaluation, Vol. 8 No. 4, pp 303-335.

[10] Akter, M and Hoque, M. (1993) 'Disclosure Practices in Bangladesh: A Case Study of the Banking Sector', Dhaka University Journal of Business Studies, Vol. 14, No. 2, pp. 2942.

[11] Bhattacharjee, S. and Hossain, M. S. (2010) 'Determinants of Financial Reporting Outcomes Following IFRS AdoptionImplications for Bangladesh', The Bangladesh Accountant, Vol. 68, No. 38, pp. 10-19.

[12] Bokpin, G. A. (2013) 'Determinants and value relevance of corporate disclosure: Evidence from the emerging capital market of Ghana', Journal of Applied Accounting Research, Vol. 14 No. 2, pp. 127-146.

[13] Buzby, S. L. (1974) 'The nature of adequate disclosure', Journal of Accountancy, Vol. 49: pp 38-47.

[14] Chithambo, L. and Tauringana, V. (2014) 'Company specific determinants of greenhouse gases disclosures', Journal of Applied Accounting Research, Vol. 15 No. 3, pp. 323-338

[15] Ferdous, C. S. (2012) 'Compliance with Codes of Corporate Governance in Developing Economies: The Case of Bangladesh', PhD, University of Birmingham.

[16] Galani, D., Alexandridis, A. and Stavropoulos, A. (2011) 'The Association between the Firm Characteristics and Corporate Mandatory Disclosure: the Case of Greece', World Academy of Science, Engineering and Technology, pp. 1048-1054.

[17] Haque, T., Jahan, M. A. and Khan, M. H-U-Z. (2007) 'Corporate Disclosures through Directors' Report-Compliance of the Companies Act 1994', The Cost and Management, Vol. 35 , No. 1, pp. 28-35.

[18] Hasan, T., Karim, W. and Quayes, S. (2008) 'Regulatory change and the quality of compliance to mandatory disclosure requirements: evidence from Bangladesh', Research in Accounting Regulation, Vol. 20, pp. 193-203.

[19] Hassan, O. A. G., Romilly, P., Giorgioni, G. and Power, D. (2009) 'The value relevance of disclosure: Evidence from the emerging capital market of Egypt', The International Journal of Accounting, Vol. 44, pp. 79-102. 
[20] Hossain, M. (2008) 'The Extent of Disclosure in Annual Reports of Banking Companies: The Case of India', European Journal of Scientific Research, Vol. 23, No. 4, pp. 659-680.

[21] Hossain, M., Islam, K. and Andrew, J. (2006) 'Corporate Social and Environmental Disclosure in Developing Countries: Evidence from Bangladesh', Working paper, Faculty of Commerce, University of Wollongong.

[22] Hossain, D. M., Khan, A. R and Yesman, I. (2004) 'The Nature of Voluntary Disclosures on Human Resource in the Annual Reports of Bangladeshi Companies', Dhaka University Journal of Business Studies, Vol. 25, No. 1, pp. 221-228.

[23] Houqe, M. N. (2004) 'Accounting Disclosure and Measurement: A Critical Evaluation of Hakansson's Model', Dhaka University journal of Business Studies, Vol. 25, No. 1, pp. 167-173.

[24] Islam, S., Hosen, A. and Islam, M. (2005) 'An Examination of Corporate Environmental Disclosure by the Bangladeshi Public Limited Companies', Pakistan Journal of Social Sciences, Vol. 3, No. 9, pp. 1095-1102.

[25] Izah, K. N., Ismail, K. and Chandler, R. (2005) 'Disclosure in the Quarterly Reports of Malaysian Companies', Online, Available at www.google.com (visited March 5, 2009)

[26] Khan, A. R., Siddiqui, J. and Hossain, D. M. (2004) 'Reporting on Corporate Governance as a Voluntary Disclosure: A study on the Annual Reports of BEXIMCO Group', Dhaka University Journal of Business Studies, Vol. 25, No. 1, pp. 131-145.

[27] Karim, AKM. W. and Ahmed, J. U. (2005) 'Determinants of IAS disclosure compliance in emerging economy: Evidence from exchange-listed companies in Bangladesh', Working paper series, No. 21, pp. 1-23.

[28] Lopes, P. T., Rodrigues, L. L. (2007) ‘Accounting for financial instruments: An analysis of the determinants of disclosure in the Portuguese stock exchange', The International Journal of Accounting, Vol. 42, pp. 25-56.

[29] Naser, K. and Nuseibeh, R. (2003) 'Quality of financial reporting: evidence from the listed Saudi nonfinancial companies', The International Journal of Accounting, Vol. 38, pp. 41-69.

[30] Naser, K., Al-Khatib, K, and Karbhari, Y. (2002) 'Empirical evidence on the depth of corporate information disclosure in developing countries: The case of Jordan', International
Journal of Commerce \& Management, Vol. 12, No. 3 \& 4, pp. 122-155.

[31] Owusu-Ansah, S. (1998) 'The Impact of corporate attributes on the extent of mandatory disclosure and reporting by listed companies in Zimbabwe', The International Journal of Accounting, Vol. 33, No. 5, pp. 605-631.

[32] Parry, M. J. 1989 'The Role of Accounting in the Economics Development of Bangladesh', Ph. D. Dissertation, University of Wales.

[33] Rahman, M. M. (1999) 'The Extent of Mandatory and Voluntary Financial Disclosure by Listed Companies in Bangladesh: An Empirical Study', Dhaka University Journal of Business Studies, Vol. 20, No. 1, pp. 189-208.

[34] Riazuddin, M., Iqbal, M. M. and Reza, S. M. (2006) 'Disclosure Practices: A Comparison of Commercial Banks and Insurance Companies in Bangladesh', The Cost and Management, Vol. 34, No. 1, pp. 16-28.

[35] Sarker, B. and Ahmed, H. (2007) 'Disclosure on Corporate Governance by Listed Companies in Bangladesh', The Cost and Management, Vol. 35, No. 1, pp. 19-27.

[36] Sejjaaka, S. (2003) 'Corporate Mandatory Disclosure by Financial Institutions in Uganda', Online, Available at www.google.com.

[37] Siddique, M. A. B. and Islam, M. R. (2010) 'Disclosure Practices of Insurance Companies in Bangladesh: Study on Some Selected Insurance Companies', The Cost and Management, Vol. 39, No. 3, pp. 27-30.

[38] Thompson, P. and Yeung, M. C. H. (2006) 'The Determinants of Transparency for Singaporean Listed Companies', Research Paper Series, Division of Business and Management, University of Nottingham in Malaysia. Available at http://www.unim.nottingham.ac.uk/dbm

[39] Wallace, R. S. O. (1988) 'Corporate financial reporting in Nigeria', Accounting and Business Research, Vol. 18 (72): pp 352-365.

[40] Wallace, R. S. O. and. Naser, K. (1995) 'Firm-Specific Determinants of the Comprehensiveness of Mandatory Disclosure in the Corporate Annual Reports of Firms Listed on the Stock Exchange of Hong Kong', Journal of Accounting and Public Policy, Vol. 14, pp. 311-368.

[41] Xiao, Z. (1999) 'Corporate Disclosures Made by Chinese Listed Companies', The International Journal of Accounting, Vol. 34, No. 3, pp. 349-373. 